\title{
The sedimentation history of Lake Huron and Georgian Bay: results from analysis of seismic reflection profiles
}

\author{
David M. Dobson, Theodore C. Moore, Jr. \& David K. Rea \\ Department of Geological Sciences, University of Michigan, Ann Arbor, MI 48109 \\ Received 3 March 1994; accepted 15 December 1994
}

Key words: seismic stratigraphy, sediment accumulation, Great Lakes, Holocene Lake Huron

\begin{abstract}
An extensive seismic reflection profile survey conducted concurrently with a sediment coring program in northern Lake Huron, Georgian Bay, and the North Channel revealed a detailed Holocene lake level history. Seven acoustic sequences were identified in the seismic stratigraphy, and these sequences show great variation in both the character and the spatial distribution of sediment deposition through time. The depths to the acoustically-defined sequence boundaries were digitized from the analog seismic records and merged with Loran-C navigation records from the cruise, yielding a three-dimensional record of the location of each sequence boundary. Thicknesses of the sequences were calculated from these depths, and a minimum-curvature spline surface was fit to the thickness data. These surfaces were used to construct isopach maps which show the trends in thickness of sediment accumulation throughout the lake basins for each of the sequences.

${ }^{14} \mathrm{C}$-AMS dates of materials from the cores fixed the dates of the sediment sequence boundaries, allowing sediment accumulation rates to be calculated. The distribution of sedimentation in the basins as shown on the isopach maps allowed assessment of sediment transport and water flow through the basins over time, which when combined with the work of Lewis \& Anderson (1989), provides a detailed record of the transport and drainage of water through these basins as the Wisconsinan ice sheet retreated and isostatic rebound opened and closed outlets. Reversals of flow direction through the Straits of Mackinac and through the channels connecting Lake Huron and Georgian Bay and the North Channel are indicated by changes in sediment thickness distributions.
\end{abstract}

\section{Introduction}

Water levels in the Laurentian Great Lakes during the early Holocene were largely controlled by the location of the shrinking Wisconsinan ice sheet and the isostatic rebound of lake outlets. Major fluctuations occurred when drainage channels were opened or closed by the removal of ice blockage or by rebound of previously depressed crust (Lewis \& Anderson, 1989). The melting glaciers not only provided a large supply of fresh water (Teller, 1990) but also left behind a massive amount of finely ground, loosely aggregated sediments which were easily transported by meltwater (Rea et al., 1981; Rea et al., 1994a). These sediments entered the developing Great Lakes, and the accumulations they produced have been the subject of many studies (Hough, 1958; Thomas et al., 1973; Kemp et al., 1974; Graham \& Rea, 1980; Johnson, 1980; Colman et al., 1990; Cameron, 1991; Foster \& Colman, 1991; Hutchinson et al., 1993). The distribution of areas of sediment accumulation has changed through time along with the fluctuation in lake levels, and these accumulation patterns can be very helpful in interpreting the occurrence, direction, and magnitude of water flow through and between lake basins.

In August and September of 1991, we surveyed northern Lake Huron and Georgian Bay with the intent of examining spatial and temporal trends in sediment composition and accumulation and developing a detailed model for the variation in lake levels in the Huron basin following the retreat of the Wisconsinan ice sheet. To further these goals, a number of types of samples and data were collected, including piston and gravity sediment cores, side-scan sonar records, and 
seismic reflection profiles. Description and interpretation of the cored sediments (Rea et al., 1994a) and the seismic profiles (Moore et al., 1994) have already been completed. The oxygen- 18 isotopic values of lake waters in several of the lake basins have been presented by Rea et al. (1994b) and used to interpret the extent of hydraulic exchange among these basins. Here we build on these findings and focus on the depositional patterns of previously defined seismic sequences in hopes of revealing the primary sediment source areas and transport pathways of the Lake Huron-Georgian Bay area throughout the Holocene.

Thomas et al. (1973) found that grain size in lake sediments is correlated with water depth, and that water depth is the controlling factor with regard to energy of the lake-bottom depositional environment. When lake levels fall, the relatively higher energy environment at the lake floor results in coarser sediment. This effect can be seen at all water depths within a lake basin, but in shallow parts of lakes a drop in lake level may lead to erosion and removal of previously deposited sediment. The coarse sediment layers generated by a lake level fall produce reflecting horizons in acoustic seismic records, and where these horizons truncate each other, paleoshorelines and paleodepth can be estimated (Moore et al., 1994). Our profiles showed that the modern lake floor and seven of the subsurface reflectors exhibited erosional truncation of underlying horizons and were traceable over a wide geographic range. These reflectors were interpreted as sequence boundaries (in the sense of Vail et al., 1977) and were traced throughout the seismic records (Fig. 1).

These interpretations were confirmed by our other data sets. Sedimentological analyses of the piston and gravity cores taken during the cruise showed coarser grain size and increased sediment bulk density where cores penetrated sequence boundaries (Rea et al., 1994a). Synthetic seismograms produced from core sound velocity and bulk density measurements matched well with the underway seismic records (Moore et al., 1994), so the interpretation of the coarsegrained reflectors as denoting relative lowstands of lake level seems justified.

A series of maps of sequence thickness (isopach maps) were created from the seismic data. Foster \& Colman (1991) have produced isopach maps of general sedimentation in Lake Michigan from acoustic seismic profiles, but without the regression and surface-fitting used in this work and without the temporal resolution available from the more detailed sequence stratigraphy developed in this project (Moore et al., 1994). A detailed seismic data set has not been available for Lake Huron before, so this history of depositional patterns within the lake basins will be of aid in carrying out future studies of lake sediments as well as providing basic data on the changing path of sediment transport through time.

\section{Data and interpretive methods}

The areas of the lake encompassed in this study are shown on Fig. 2. The survey provides a fairly detailed record of north central Lake Huron and much of Georgian Bay. The seismic reflection profiles were collected on the R/V Laurentian using an IKB Seistec high-resolution profiler which emitted and recorded high-frequency $(2-10 \mathrm{kHz})$ seismic pulses. The analog seismic reflection records were interpreted by Moore et al. (1994) who found seven sub-surface horizons which were traceable through northern Lake Huron and Georgian Bay. Seismic sequence boundaries were assigned the names of colors by Moore et al. (1994) for purposes of identification and discussion (Fig. 3), and that convention has been followed here for consistency. Not all of the reflective layers marking the sequence boundaries were present in all locations; some were absent due to erosion, and some were impossible to track because of a loss of acoustic impedance contrast or a thinning of layers.

\section{Overview of seismic sequences}

The seismic stratigraphy developed from the records is more detailed than that found in other lakes (Hutchison et al., 1993; Foster \& Colman, 1991; Thompson, 1980; Kemp et al., 1974), with more sequences identified and traced (Moore et al., 1994; Table 1). ${ }^{14} \mathrm{C}$ AMS dating and other age estimates indicate that the sequences bounded by the reflectors represent widely varying time intervals. The Purple sequence boundary, lowest in the section, is the acoustic basement of the lakes and is assumed to divide glacial till (or in some cases Paleozoic bedrock) below from lacustrine sediments above. The Dark Blue sequence boundary is not well defined, often being truncated by the overlying Dark Green sequence boundary and usually appearing in thicker sections, if at all. Sediment accumulation between the Purple and the Dark Green sequence boundaries tends to fill in bathymetric lows. The Orange is one of the best-defined sequence boundaries and has a very wide distribution, appearing in 


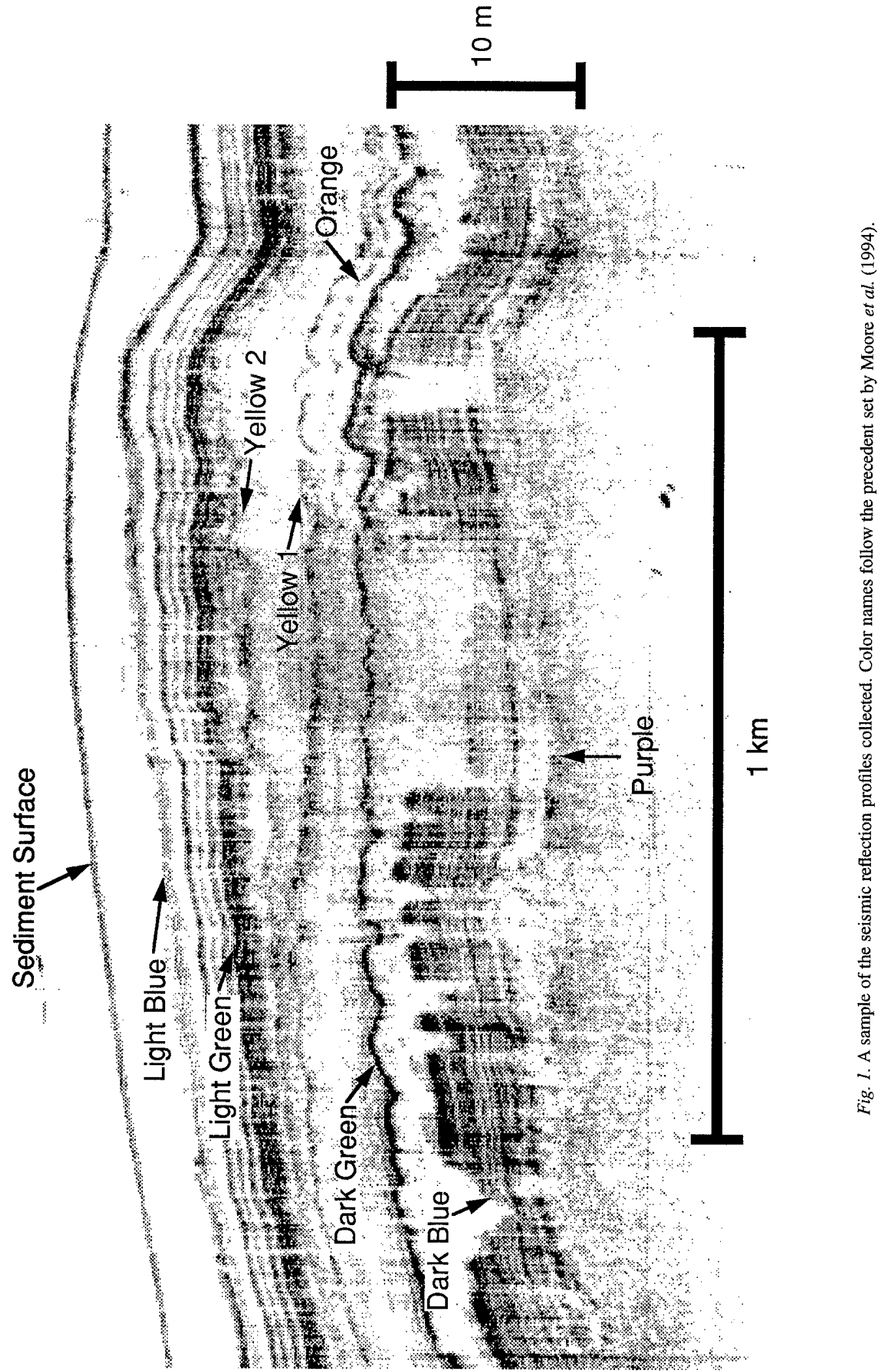




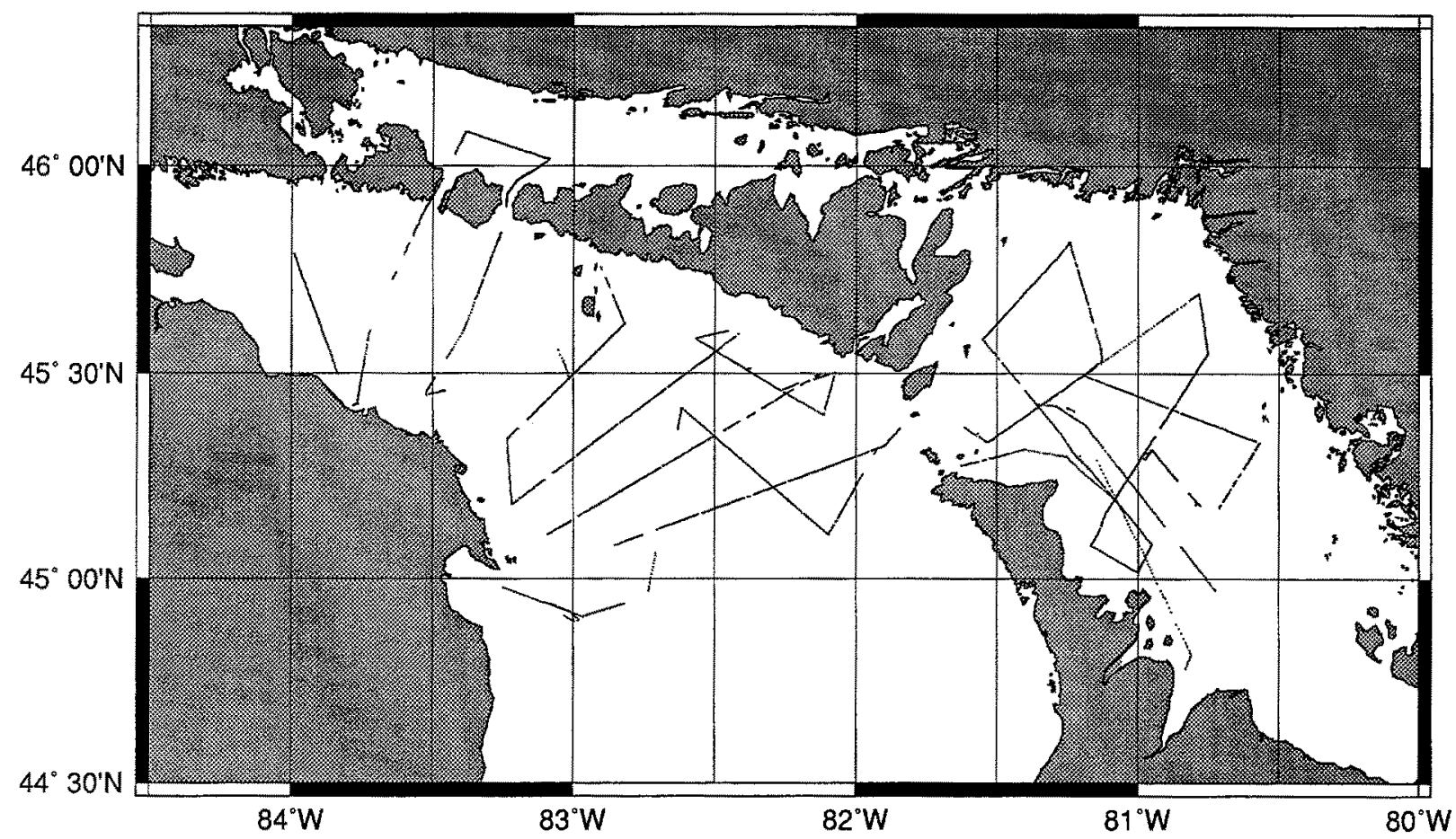

Fig. 2. Seismic survey path. Not all sequence boundaries were present at all locations.

most sections. The Yellow sequences have an extremely limited spatial range, appearing mostly in central Lake Huron. The two Yellow sequences appear to have been eroded away in many areas during the lowstand associated with the Light Green sequence boundary. The Light Green sequence boundary is the best-defined of all, and is a pronounced truncator of older horizons. It sometimes appears as a doublet reflector, indicating that it may have been a complex event. The Light Blue horizon represents the youngest lowstand and has a wide distribution. The modern lake bottom is also considered to be a sequence boundary because erosion and redistribution of sediments is occurring today.

\section{Data processing}

To manipulate the information contained in the seismic records, it was necessary to convert them to a numeric format, which was done using a Summagraphics Summagrid III digitizing table. The sequence boundaries were digitized at a density of approximately one point every 5 meters of horizontal distance. The depth to each sequence boundary was calculated using a uniform sound velocity in the sediments of $1480 \mathrm{~m} \mathrm{sec}^{-1}$. The data were then merged with data from the Laurentian's Loran-C navigation.
The thickness of each sequence was obtained by subtracting the depth of one sequence boundary from the depth of another. These thicknesses could only be calculated in areas where both of the boundaries of the sequences to be measured are present. Thicknesses for all combinations of sequence boundaries were calculated. Sediment thicknesses thus calculated are minima. Sediments from an older sequence may be eroded during low lake levels in shallow areas and then either redeposited elsewhere in the basin as a part of a newer sequence or transported away from the basins entirely. Thus, the sediment remaining in a sequence may not represent the entire amount deposited during the time interval between the sequence boundaries. Furthermore, the average linear sedimentation rates (LSR's), which are calculated by dividing thickness of a sequence by the time span it represents (the difference in the ages of the sequence boundaries), may in actuality have been higher than the values calculated (Table 1). Maximum sedimentation rates tend to occur in the deepest areas of the lake basins which are less subject to erosion, so the maximum sedimentation rates shown are likely close to the true maxima.

Once the thicknesses were determined, the data were run through a mean-value gridding program. This created a two-dimensional matrix of values with each 


\section{STRATIGRAPHY}

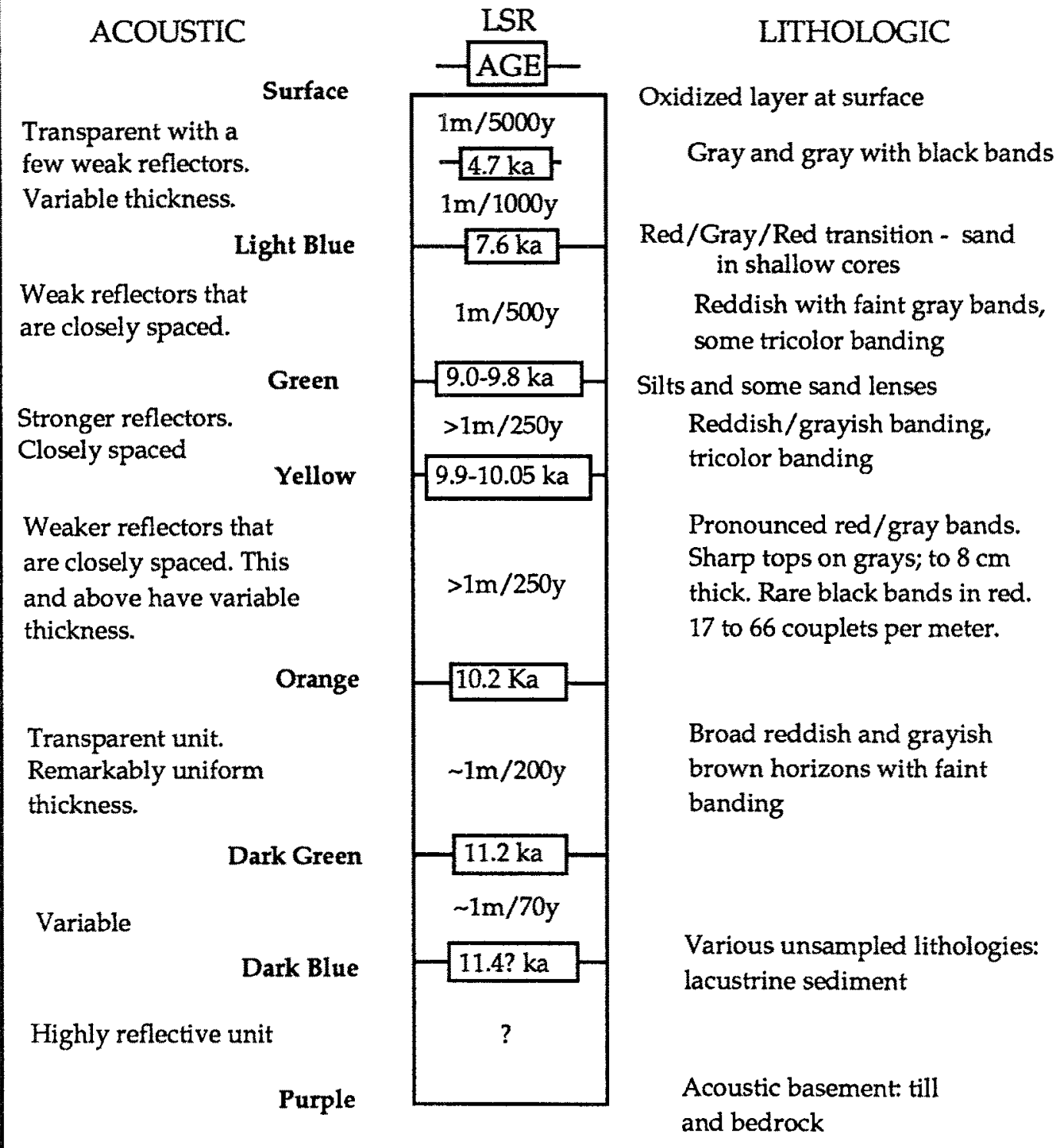

Fig. 3. Summary of stratigraphy for northern Lake Huron and Georgian Bay sediments (after Rea et al., 1994a). Seismic character of sequences and boundaries was described initially by Moore et al. (1994). Detailed description of lithostratigraphy appears in Rea et al. (1994a). Sedimentation rates updated from those given by Rea et al. (1994a) by this work (see Table 1).

value representing a block of latitude and longitude. For the analyses described herein, the block sizes were 1 minute of longitude by 0.6 minutes of latitude, which in the vicinity of Lake Huron produces roughly square blocks approximately 1000 meters on a side. The values were calculated by taking the mean of all values within the block weighted by their distance from the center of the block.
Because a feature on the maps would have to be made up of several of these grid blocks to be identifiable, the smallest resolvable feature on these maps is on the order of a few kilometers. The seismic records give much more detail than this on local scales (tens or hundreds of meters), but the gridding procedure compensates for its loss of fine resolution by averaging effects of very localized bathymetric variation and 
Table 1.

\begin{tabular}{|c|c|c|c|c|c|c|c|c|}
\hline Sequence & $\begin{array}{l}\text { Age of base } \\
\text { reflector (ka) }\end{array}$ & $\begin{array}{l}\text { Duration } \\
\text { (y) }\end{array}$ & $\begin{array}{l}\text { Maximum } \\
\text { thickness (m) }\end{array}$ & $\begin{array}{l}\text { Mean } \\
\text { thickness (m) }\end{array}$ & $\begin{array}{l}\text { Depocenters } \\
\text { (see Figure 4) }\end{array}$ & $\begin{array}{l}\text { LSR } \\
\text { Max }\end{array}$ & $\begin{array}{l}(\mathrm{cm} / \mathrm{y}) \\
\text { Mean }\end{array}$ & $\begin{array}{l}\text { Sediment } \\
\text { character }\end{array}$ \\
\hline Lt. Blue - Sed/Water & 7.6 & 7600 & 19 & 2.0 & $3,7,4,1$ & 0.2 & 0.03 & $\begin{array}{l}\text { Gray, gray with } \\
\text { black bands }\end{array}$ \\
\hline Lt. Green - Lt. Blue & $9.0-9.8$ & 1800 & 29 & 4.3 & $1,3,2,5$ & 1.6 & 0.2 & $\begin{array}{l}\text { Red with gray } \\
\text { bands }\end{array}$ \\
\hline Yellow - Lt. Green & $9.9-10.05$ & 600 & 11 & 2.4 & $5,3,8$ & 4.9 & 0.4 & $\begin{array}{l}\text { Less clear red/gray } \\
\text { bands, tricolor bands }\end{array}$ \\
\hline Orange - Lt. Green* & 10.2 & 900 & 25 & 3.8 & $6,5,7$ & 5.6 & 0.4 & $\begin{array}{l}\text { Distinct red/gray } \\
\text { bands, sequences } \\
\text { reach } 6-8 \mathrm{~cm}\end{array}$ \\
\hline Dk. Green - Orange & $11.2^{* *}$ & $1000(?)$ & 23 & 4.9 & $8,5,6$ & $2(?)$ & $0.5(?)$ & $\begin{array}{l}\text { Thick reddish/grayish } \\
\text { brown units, some } \\
\text { banded }\end{array}$ \\
\hline Dk. Blue - Dk. Green & $11.4^{* *}$ & $200(?)$ & 14 & 2.6 & 4,5 & $7(?)$ & $1.5(?)$ & Uncored \\
\hline Basement - Dk. Blue & $? ?$ & $? ?$ & 33 & 3.8 & $8,7,3$ & $? ?$ & $? ?$ & Uncored \\
\hline
\end{tabular}

The thicknesses were calculated from the digitized seismic records, before gridding and surface fitting.

LSR is the Linear Sedimentation Rate, calculated by dividing thickness by duration.

* Note that this interval includes the Yellow - Lt. Green interval immediately above.

This combination of sequence was necessary because of the limited spatial extent of the Yellow reflector group.

** These ages are estimates and lack support from our cores.

bringing out larger-scale features and trends in sediment thicknesses.

\section{Surface-fitting techniques and contouring}

For this study, a continuous curvature surface with an added factor of tension was applied to the gridded thickness data using the GMT software package (Wessel \& Smith, 1991). This tension factor affects the surface generated as if it had been stretched, allowing a relaxation of the continuous curvature requirement for the surface (i.e. allowing the surface to become slightly kinked) and greatly reducing the range of extrapolated very high and low values which led to the surrealistic results of the continuous curvature model (Smith \& Wessel, 1990). The extent of the stretching is controlled by a tension parameter, $T$, varying between 0 and 1 , which is supplied subjectively by the modeler, with $T=0$ being the true continuous curvature case and $T=1$ devolving to a solution very similar to nearestneighbor averaging. Wessel \& Smith $(1990,1991)$ suggest a tension factor of 0.35 for bathymetric mapping. Because the isopach maps are similar in nature to bathymetric mapping and because the same problems Wessel \& Smith mention for high and low tension mod- els appear to apply to the data of this study, a tension factor of 0.35 was adopted for the purposes of this work.

The use of this technique rather than handcontouring calculated thicknesses was a decision made for several reasons. As mentioned above, the gridding process reduces the complicating effects of local bathymetric features, which can exert a strong control over sediment accumulation on a small scale but which may disguise the larger-scale trends in the data. This is especially helpful since the Lake Huron-Georgian Bay basins have not been extensively surveyed using modern bathymetric techniques, and only their broad bathymetric trends are well-known. Although the survey data set used here is extensive, it is not adequate for a truly detailed definition of small scale bathymetric features.

Computer surface-fitting also has several advantages over hand-contouring for this data set. Most importantly, the computer processing is both extrapolative and interpolative, which allows for a reasonable guess at thicknesses in areas with few or no data, a guess based on trends apparent in areas where the thicknesses are defined. Also, the surface-fitting is a statistical regression, which means that the process is 
objective, uncolored by individual interpretations (but also lacking in insight). Finally, the large thickness database can easily be accessed, displayed, modified, or re-contoured with different parameters, and with all of the programs and data-management techniques now in place, the data set may readily be enlarged when future data from seismic surveys or other sources become available.

The surfaces fit to the thickness data can be plotted in two dimensions as isopach maps to aid in interpretation. Each interval in the history of the Lake HuronGeorgian Bay basin will be discussed below. Figure 2 is useful in showing where within the lake boundaries the surface is best supported by data and where the fitted surface is an interpolation or extrapolation. Where necessary, modern names of locations and channels (Fig. 4) have been used to aid in description and discussion, and bathymetric maps have been provided for reference for modern lake depths (Fig. 5a, b).

The gridding resolution and contouring of the data set produces some 'bull's-eye' features which follow the ship track lines. These could have been removed by lowering the gridding resolution during intervals in which they occur, but this would have limited our ability to compare features on different maps. For this reason, the $1 \mathrm{~km}^{2}$ grid size, a resolution which is appropriate for most intervals, was used for all of the maps.

\section{Interpretive rationale}

These isopach maps can reveal important information about both the character of sedimentation and about its transport, and from these observations the direction of water flow during sediment deposition can be inferred. The best evidence of flow direction in these maps is thick accumulations near flow restrictions such as the Mississagi Strait, False Detour Channel, the Straits of Mackinac, and the wide channel connecting Lake Huron and Georgian Bay. The fundamental assumption used in our interpretation of these accumulations is that as water slows after passing rapidly through a restricted channel, its capacity to transport sediment decreases and suspended sediment drops out, leaving thick accumulations on the downstream side of the channel and possibly eroding some existing sediment within the channel.

Bathymetry of the lake plays a very important role in determining the distribution of sediment accumulation. In many instances, more sediment has accumulated in deeper areas of the basins, most likely as a result of faster currents and more erosion in shallower areas.
Two representations of lake bathymetry are included here, the first of which (Fig. 5a) was derived from soundings taken by the National Oceanic and Atmospheric Administration (Ristic, 1989), and the second of which was created by the same surface-fitting technique applied to the thickness data - a continuous curvature surface under tension was fit to the depths of the Sediment Surface sequence boundary, which is the modern lake bottom (Fig. 5b). The two maps agree relatively well in areas covered by the seismic survey (Fig. 2) and less well when the surface-fitting process extrapolates the depths of unsurveyed regions.

The ages of the sequence boundaries have been established through ${ }^{14} \mathrm{C}$ AMS dating of materials recovered from the sediment cores (Rea et al., 1994a) and these ages are used here without modification. A summary of information for each sequence, including boundary ages and sedimentation rate data, is presented in Fig. 3 and Table 1. The maximum and average sequence thicknesses were calculated from the digitized seismic records directly, before gridding and surface fitting, so the maximum values may represent small scale $(<1 \mathrm{~km})$ features.

\section{Results}

\section{Isopach maps}

Isopach maps were made of each seismic sequence (Fig. 6a-f). Changes in sediment distribution in the maps are interpreted in terms of the evolution of flow patterns and sediment transport during the post-glacial development of Lake Huron, starting from the most recent interval and going back through the first retreat of ice cover from the lake basins.

\section{Light Blue to sediment surface}

Sediment accumulation patterns since the time of the Light Blue sequence boundary, a lowstand of lake level 7600 years ago, are quite complex (Fig. 6a). Sediment accumulation rates during this interval were high as the lakes rose to the Nipissing highstand at $\sim 4.7 \mathrm{ka}$ and have been steady or falling ever since (Rea et al., 1980; Colman et al., 1990). The Nipissing highstand was only slightly higher than modern lake levels (Lewis \& Anderson, 1989), implying fairly uniform sedimentation conditions for the last $4.7 \mathrm{ka}$. Erosion and reworking were relatively more active because sediment sup- 


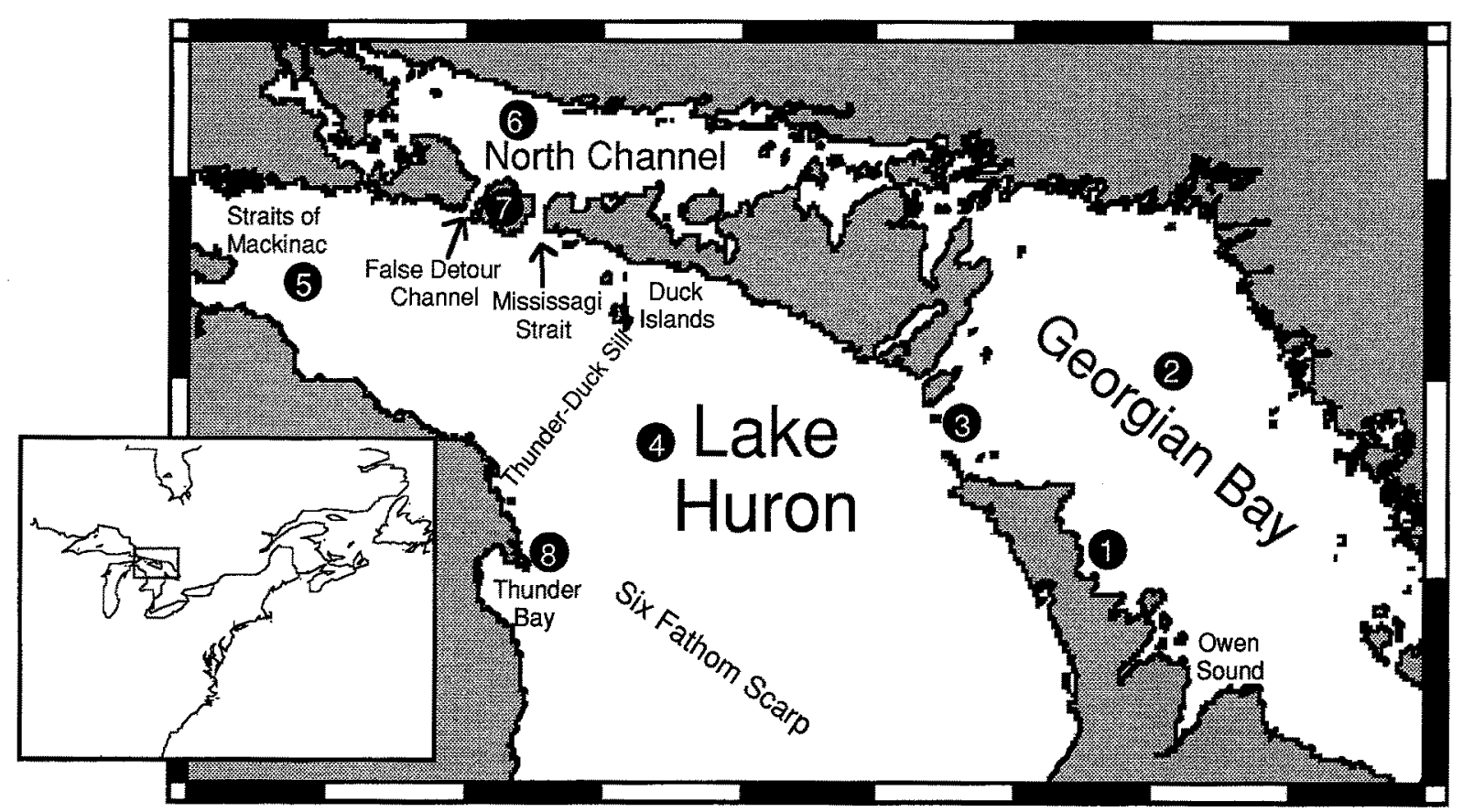

Fig. 4. Features mentioned in text. Numbered areas correspond to depocenters mentioned in Table 1.

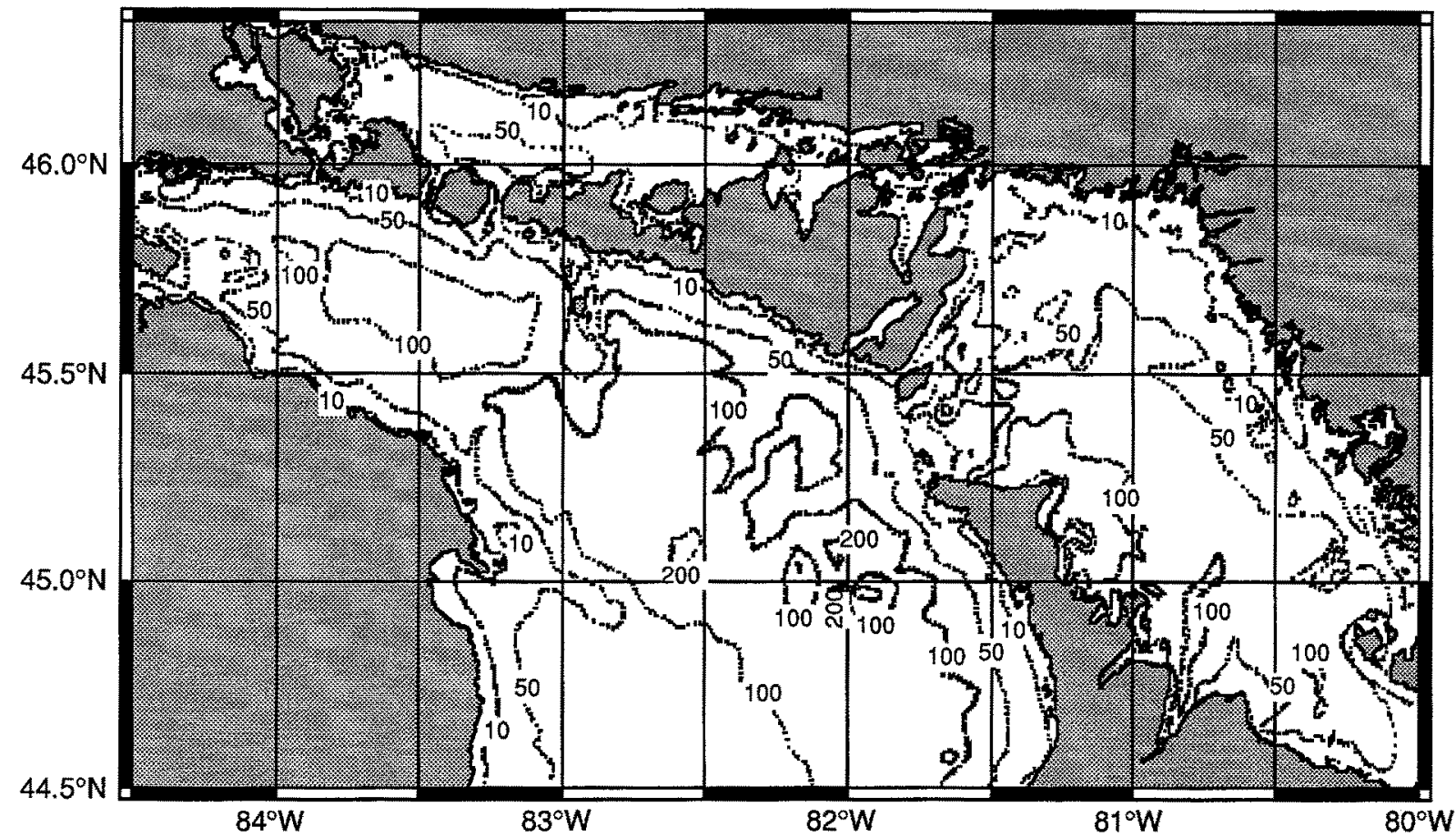

Fig. 5. Bathymetry of Lake Huron and Georgian Bay. (a) Bathymetry from Ristic (1989). Contours at 10, 50,100, and $200 \mathrm{~m}$.

ply was lower than in the earlier intervals discussed below.
A large accumulation of sediment occurs near $46^{\circ} \mathrm{N}, 83^{\circ} 30^{\prime} \mathrm{W}$ at False Detour Channel, a shallow channel between the North Channel and the northern 
Lake Huron basin. Also interesting is the convoluted sedimentation pattern in Georgian Bay (Fig. 6a). In general, the thicker accumulation (darker areas) occurs in conjunction with deep areas of that basin which are found along the southwest margin of the bay. The local bathymetry of this region seems to play a large role in determining where sediment will accumulate, and accumulation patterns are very patchy, confirming the choice of Moore et al. (1994) of the modern lake bottom as an erosional surface and a sequence boundary. There is also a thick accumulation just southwest of the channel connecting Lake Huron and Georgian Bay, which is indicative of water flow southwestward through the restricted channel between the two basins, flow which is active today (Thomas et al., 1973; Lewis \& Anderson, 1989). Also, along the Thunder-Duck sill, a bathymetrically shallow feature running from the peninsula just north of Thunder Bay $\left(45^{\circ} 15^{\prime} \mathrm{N}, 83^{\circ} 30^{\prime} \mathrm{W}\right)$ to Duck Island $\left(45^{\circ} 40^{\prime} \mathrm{N}\right.$, $\left.82^{\circ} 55^{\prime} \mathrm{W}\right)$, there is an absence of accumulation, marking this area as a zone of non-deposition and probably active erosion.

\section{Light Green to Light Blue}

Sediment accumulation just prior to the last major lowstand shows marked differences from modern patterns (Fig. 6b). This interval was a period of intermediate to near-modern water depth between approximately 9000-9800 (Light Green doublet reflector) to 7450 7750 years ago. There are very large accumulations in parts of Georgian Bay, generally filling in the bathymetric lows along the southwest side of the basin. East of the channel connecting Lake Huron and Georgian Bay a very thick pod of sediment was deposited. This was likely caused by water flowing eastward into Georgian Bay, but it must have been deposited later in the interval during the main Mattawa highstand, as ostracodes and clams from the two basins have very different oxygen isotopic ratios during the early Mattawa highstand (Rea et al., 1994b), implying that flow was predominantly from Lake Huron into Georgian Bay or that water from Georgian Bay and Lake Huron did not mix between 9600 and 9350 yrbp.

False Detour Channel and the Mississagi Straight show very little adjacent accumulation, which is a
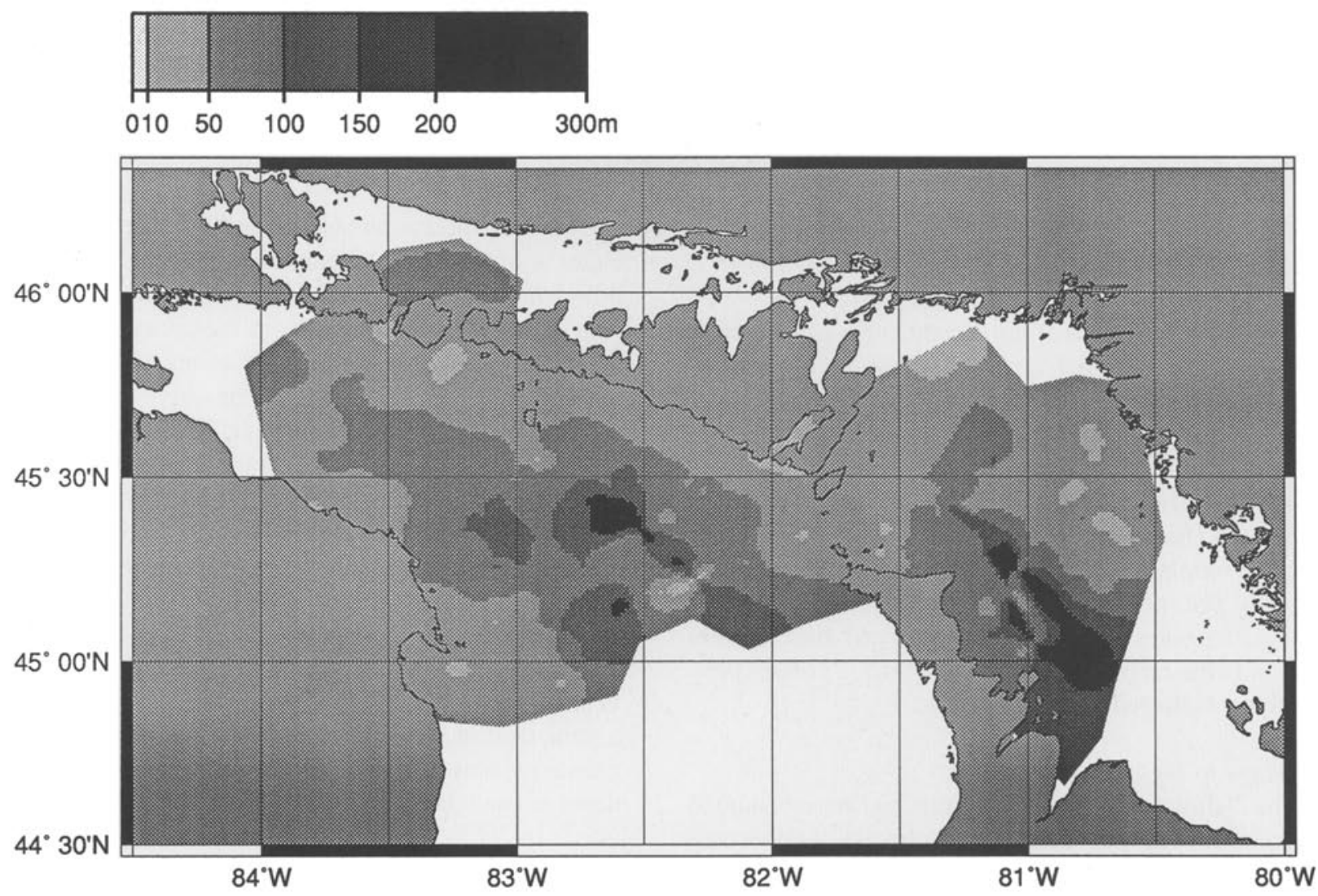

Fig. 5. (b) Bathymetry from surface-fitting on Sediment Surface sequence boundary (lake bottom). Contours at 10, 50, 100, 150, and 200 m. 

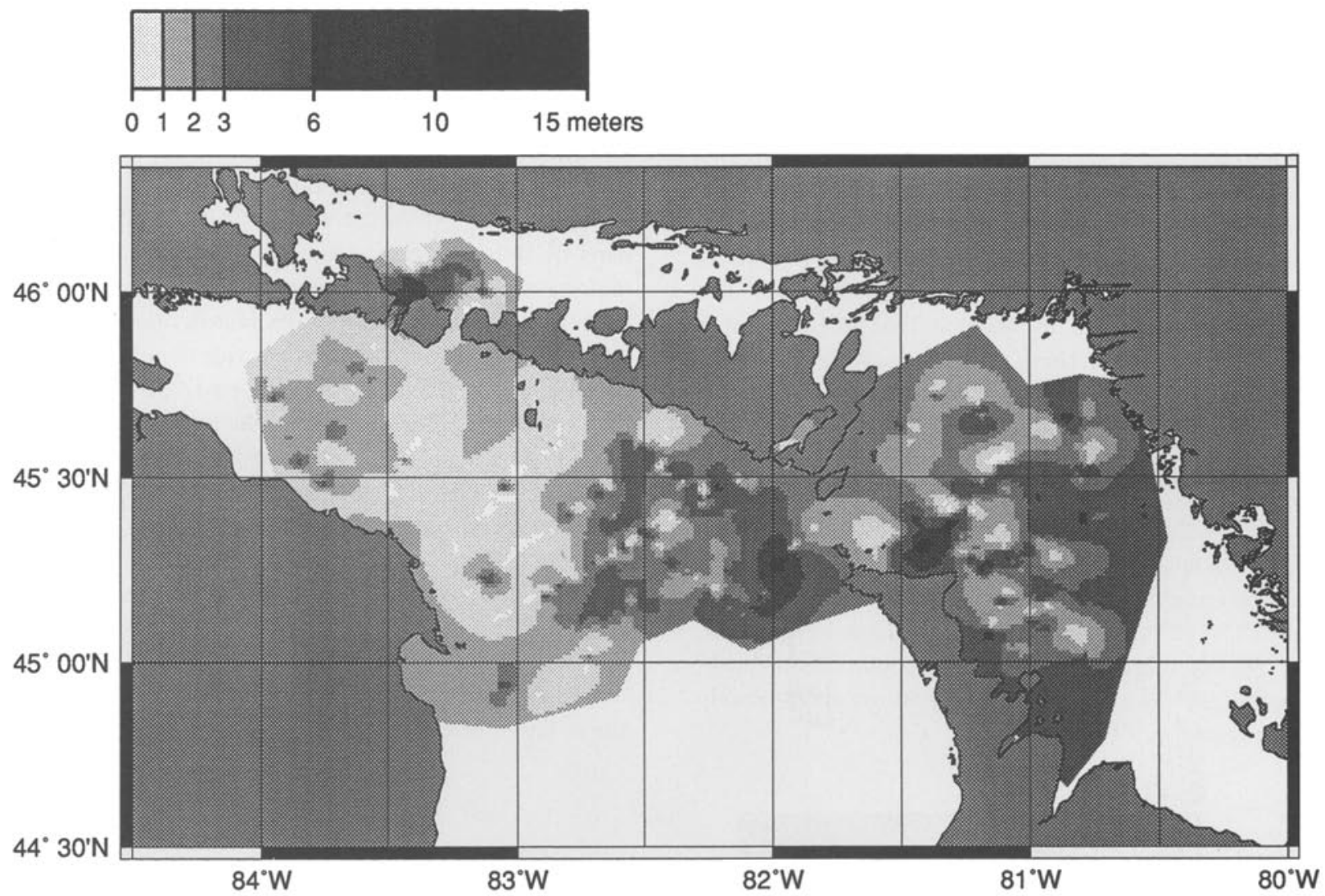

Fig. 6. Isopach maps of sediment thickness for all sequences. The thickness scale is the same for all maps. (a) Light Blue to Sediment Surface (7.6 ka to present)

marked difference from the most recent interval. The large accumulation south of these channels lies in a deep basinal area. This, and the patterns in Georgian Bay, show that much of the accumulation of sediments in the Light Green to Light Blue interval is filling deeper areas.

Note that the overall accumulations in this sequence are much thicker and that sediment accumulation rates must have been much higher than during the youngest interval, because Fig. 6a represents over 7000 years of accumulation while $6 \mathrm{~b}$ represents only about 2000 years. Sediment cores and seismic profiles reveal accumulation rates during this period many times higher than in the more stable, mid-Holocene to present period that followed (Table 1).

\section{Yellow to Light Green}

The Yellow sequence boundaries had a very limited occurrence in the seismic records because of their erosion at the time of the Light Green lowstand (Moore et al., 1994). They are only detectable in the deeper parts of Lake Huron and Georgian Bay, where a combination of higher sedimentation rates and relatively little winnowing preserved them. Nevertheless, some conclusions can be drawn from the areas in which they occur (Fig. 6c). Deposition south of Mississagi Strait indicates that there was probably significant flow southward through that channel. Limited accumulation occurs in Georgian Bay, but the thickness map still shows a thicker accumulation on the east side of the Georgian-Huron channel than on the west. If the estimated ages (Rea et al., 1994a) are correct for this poorly defined sequence boundary, sedimentation rates averaged almost a half-centimeter per year (Table 1). These rates are consistent with the varve thicknesses in this interval and indicate that the lake was receiving a great deal of terrigenous material from the melting glacial ice mass and/or from shoreline erosion during times of changing lake levels. 


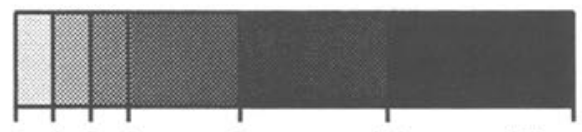

$\begin{array}{lllllll}0 & 1 & 2 & 3 & 6 & 10 & 15 \text { meters }\end{array}$

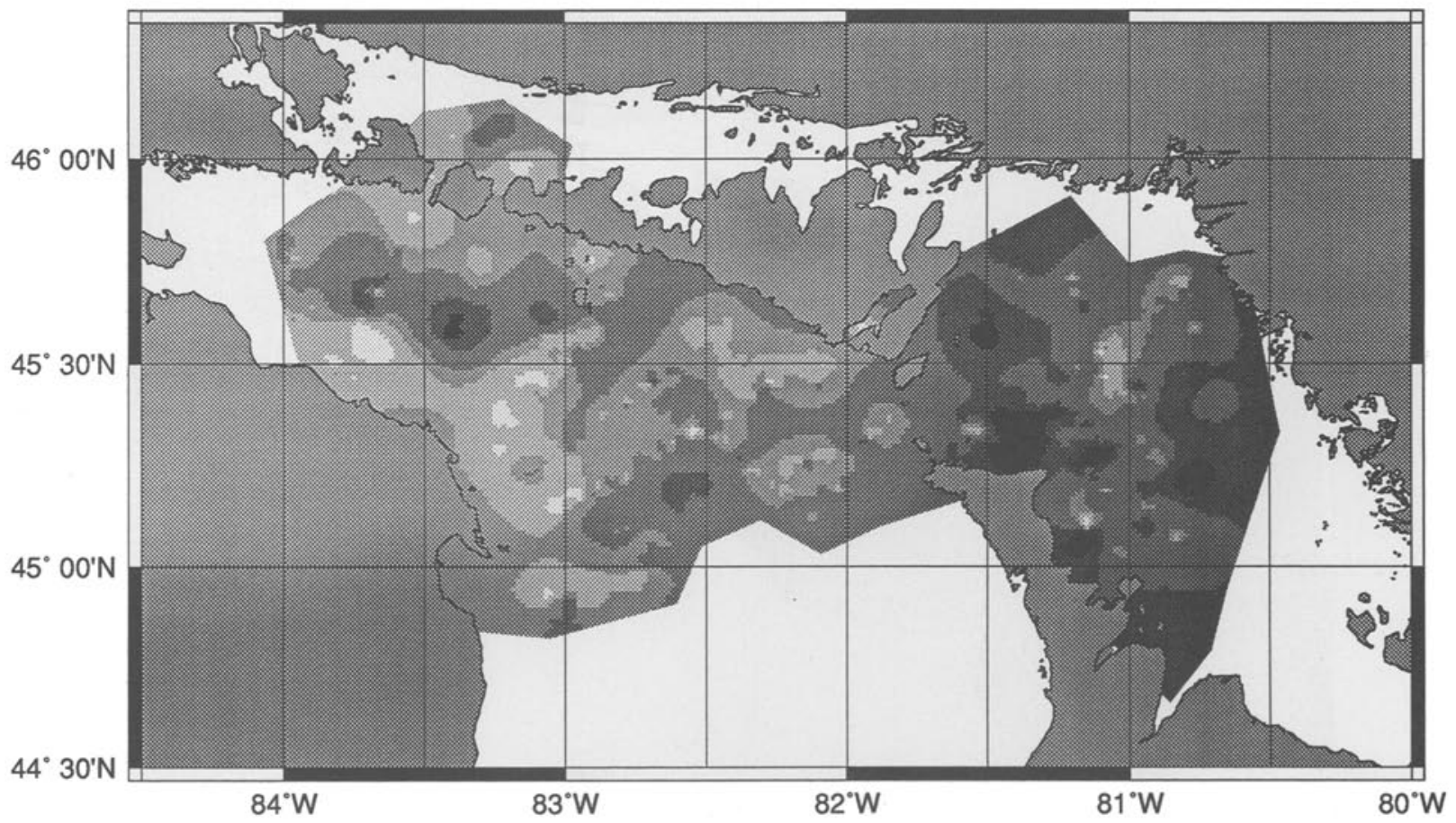

Fig. 6. (b) Light Green to Light Blue (9.3 ka to $7.6 \mathrm{ka}$ )

\section{Orange to Light Green}

This interval, which includes the Yellow sequence boundaries, shows remarkably uniform sedimentation throughout the basin, with unusually thick accumulations only occurring in the northwest part of Lake Huron and in the North Channel (Fig. 6d). The paucity of features belies the extent of data for this interval the Orange and the Light Green are two of the bestdefined sequence boundaries, occurring in nearly every seismic record. Thick accumulation in the North Channel may indicate northward flow from Lake Huron into the North Channel, which then drained eastward into Georgian Bay, or conversely, it may represent sediments transported from the Lake Superior basin or from an ice margin to the north. The flow between Lake Huron and Georgian Bay is unclear during this interval. In the extreme northwest part of the survey area, thick accumulations indicates significant water flow eastward from Lake Michigan. These sediments could well have been emplaced after the Marquette glacial advance closed off westward outlets of Lake Superior and forced drainage of meltwater through the
Whitefish Channel into Green Bay and then into northern Lake Michigan, which in turn drained into northern Lake Huron (Lewis \& Anderson, 1989).

On a basin-level scale of observation, the accumulation during this interval seems to have been fairly uniform draping rather than infilling of the deeper regions, which is supported by very rapid sedimentation rates (Table 1) and implies little reworking by flowing water or storm waves.

\section{Dark Green to Orange}

Water levels reached their maximum extent during this interval (Lewis \& Anderson, 1989). This maximum, termed the Main Algonquin highstand, peaked at approximately $180 \mathrm{~m}$ above sea level (Lewis \& Anderson, 1989; Fig. 7). Sediment accumulation during this time is fairly uniform in Georgian Bay, while Lake Huron shows thicker accumulations in deeper areas (Fig. 6e). Accumulation maxima occur in the Alpena basin offshore from Thunder Bay, in the center of the Huron basin and in the North Channel. Relatively little sediment cover collected during this interval along 


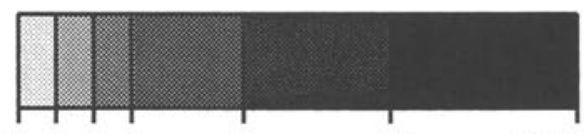
0123
6
10
15 meters

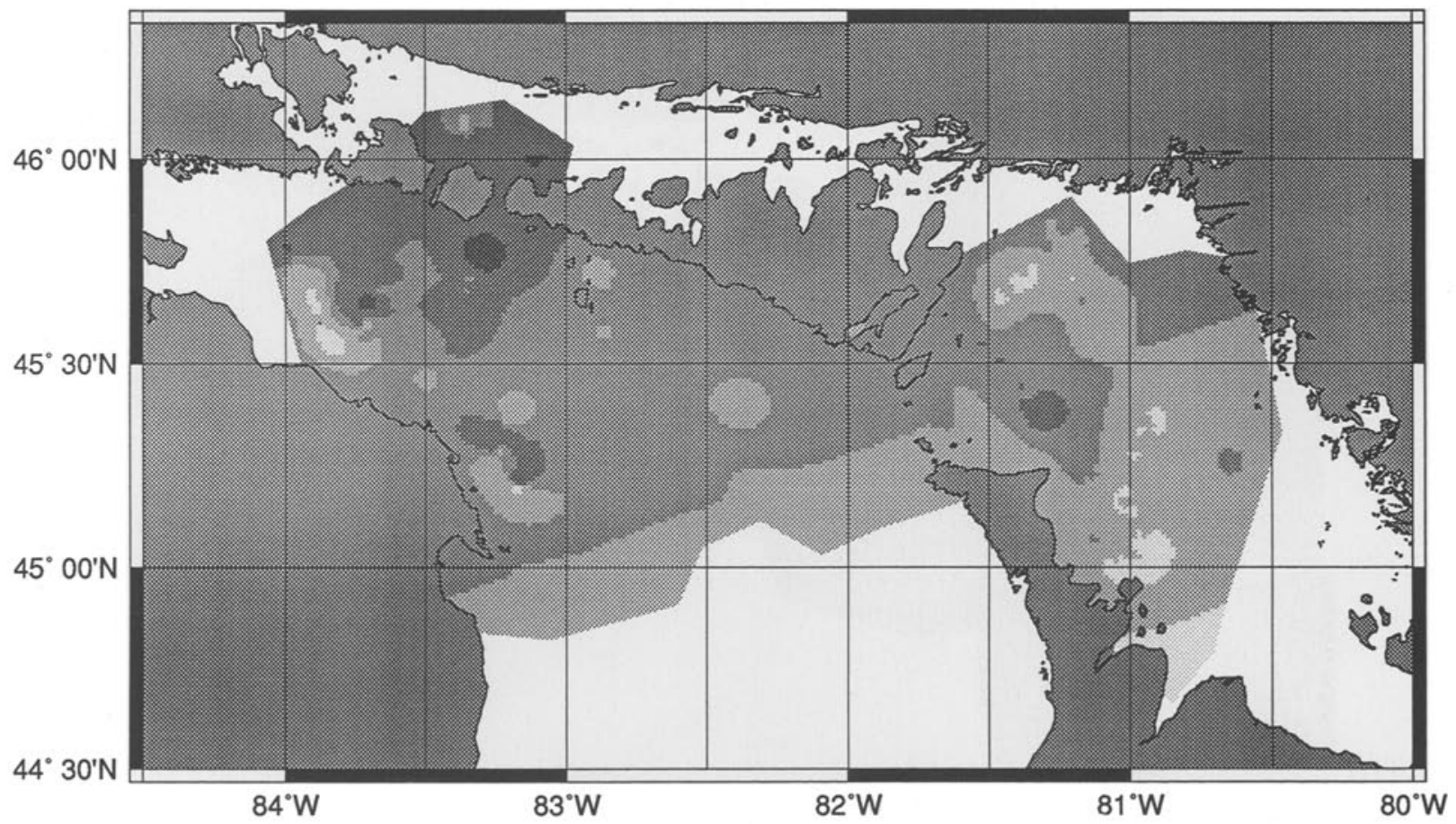

Fig. 6. (c) Yellows to Light Green (9.9 ka to $9.3 \mathrm{ka}$ ). Lack of detail is due to limited distribution of Yellow sequence boundaries.

the shallower Thunder-Duck sill and Six Fathom Scarp (Fig. 4). The thicker accumulations in deep areas could be the result of erosion or non-deposition in shallow areas caused by the large volumes of water estimated to have moved through this system at this time (Teller, 1990). The minor depocenters in the North Channel might seem to indicate flow northward from Lake Huron, but sediment delivered by Lake Superior drainage from the northwest is a source more consistent with regional drainage at this time (Lewis \& Anderson, 1989).

The age of the Dark Green and earlier sequence boundaries are not well-defined as these horizons were never penetrated by the cores taken in this survey. Rea et al. (1994a) estimate an age of $11.2 \mathrm{ka}$ for the Dark Green sequence boundary.

\section{Purple (acoustic basement) to Dark Green}

Sediment accumulation was focused in several large depocenters during the period following the retreat of glacial ice from the Huron area (Fig. 6f). As ice retreated to the north of the Lake Huron area, thick sediment accumulation occurred in the straits between Lake Huron and the North Channel and in the deep parts of northwest Lake Huron near the channel connecting Lake Huron and Georgian Bay. The isopach map shows a concentration of accumulation at the western side of the lake system not seen at later times. Sedimentation rates cannot be calculated because the exact timing of the ice retreat is not known. They are likely to have been high and variable depending on the proximity to the melting ice margin.

The juxtaposition of very thick sections with very thin sections in northwest Georgian Bay are in an area where it appears there were significant accumulations followed by uplift and erosion. Deposition followed by periods of erosion has dominated the sediment accumulation history in this region (Moore et al., 1994), reflecting the very large sediment influx from materials eroded by and formerly entrained in the ice sheet coupled with the rebound of the crust following ice retreat.

The Purple to Dark Green interval contains another major reflector, the Dark Blue, which was much more 

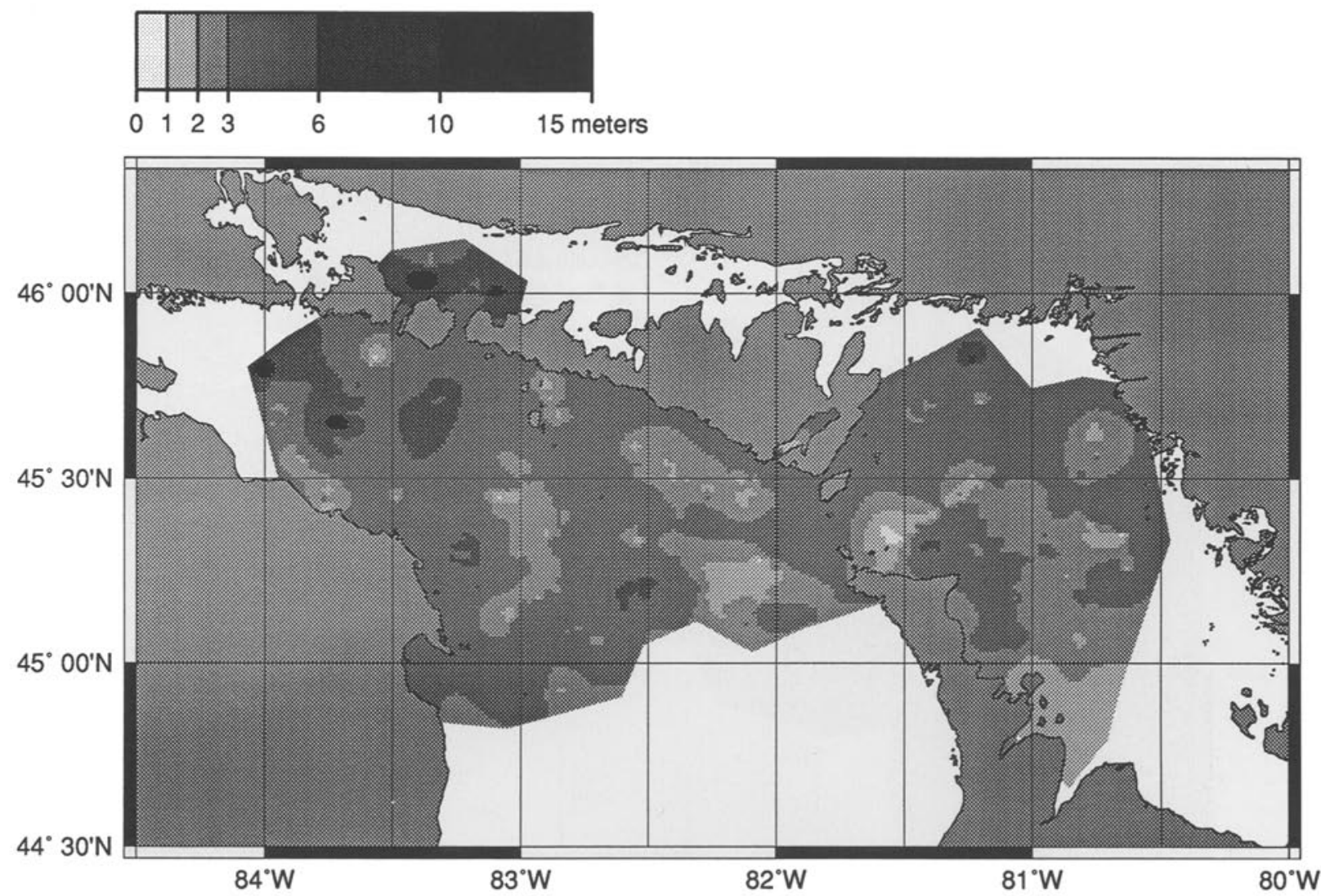

Fig. 6. (d) Orange to Light Green ( $10.2 \mathrm{ka}$ to $9.3 \mathrm{ka}$ ). This interval includes the sequence shown in Fig. 6c. This combination was necessary to preserve the detail which would have been lost if the less frequently identified Yellow sequence boundary was used for thickness calculations.

widespread in the seismic records than the Yellows but still too sparsely distributed to generate meaningful surfaces when compared with adjacent sequence boundaries. It was a major event, truncating underlying sediment over much of its extent, and has been classified as a sequence boundary and lowstand of lake level by Moore et al. (1994). Its limited appearance in the seismic records precludes its use in sediment accumulation mapping, but general sedimentation statistics for the Dark Blue can be generated (Table 1).

\section{Discussion and interpretation}

The history of sediment accumulation in Lake Huron and Georgian bay is complex, but its variation over time and space is an important source of information about regional water flow, transport directions, sedimentary processes, and mid-continent climate. The three-dimensional surface-fitting technique is a useful tool in examining the distribution of sediment accumu- lating in these lakes. A brief history of water flow can be created from a combination of prior work (Lewis \& Anderson, 1989, and sources therein; Rea et al., $1994 b)$ and the isopach maps shown here.

Lewis \& Anderson (1989) produced maps of water flow, lake levels, and drainage pathways throughout the Laurentian Great Lakes from information on paleo-shorelines, sedimentological studies, and isostatic rebound models and calculations. These maps were generally restricted to highstands where such information is better constrained. Using the patterns of sediment accumulations presented here (Fig. $6 \mathrm{a}-\mathrm{f}$ ), their findings can be augmented and refined for the Huron-Georgian Bay basin, and some of the temporal gaps in their interpretations can be filled in (Fig. 8af).

Shortly after initial retreat of the ice sheet, the lake basins remained isostatically depressed toward the north, with lake waters in direct contact with the ice sheet. Sedimentation tended to fill in deep areas (which were along the ice margin), and the Huron/Georgian 


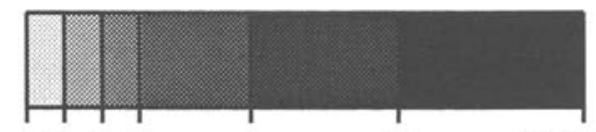
0123
6
10
15 meters

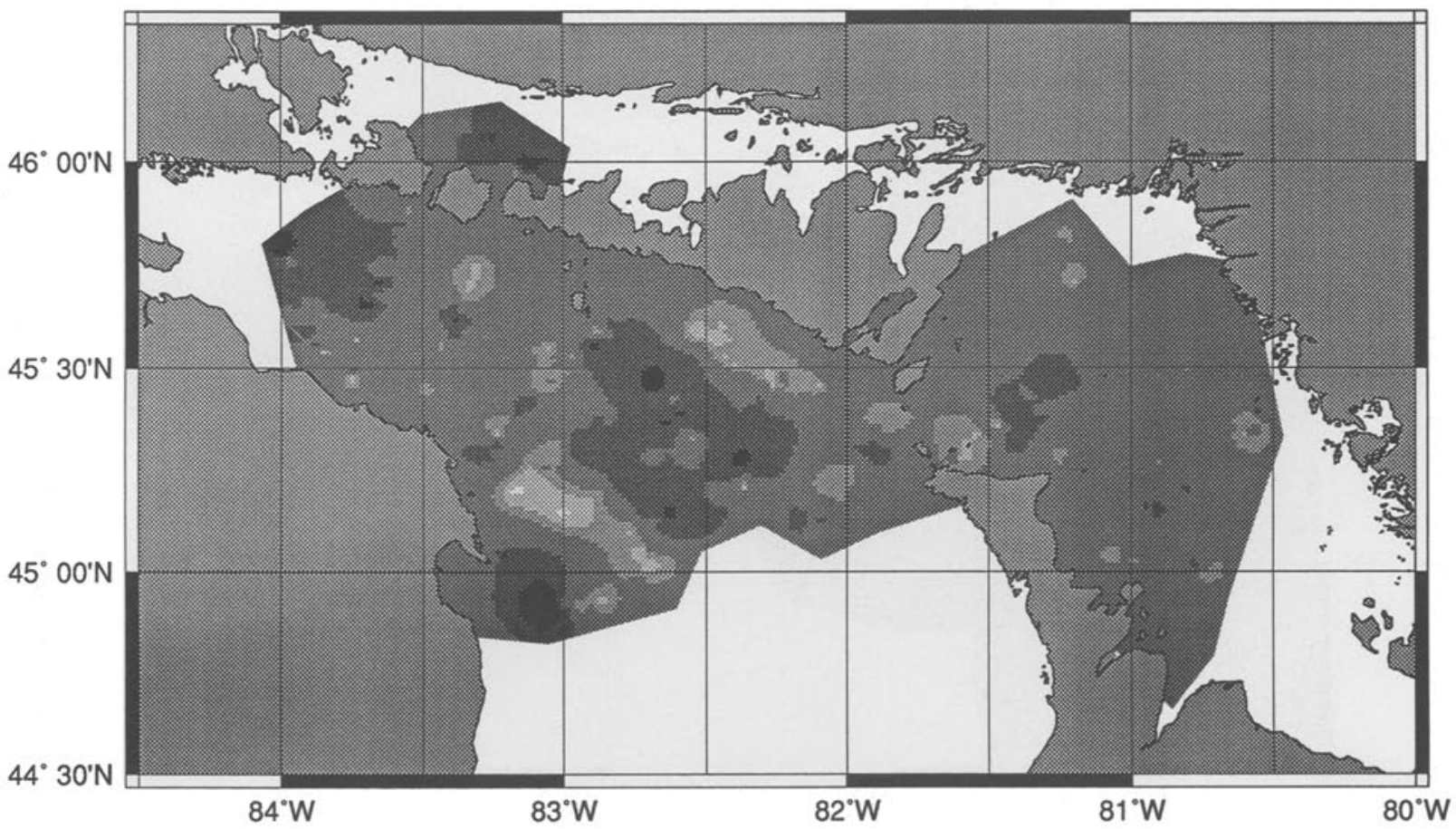

Fig. 6. (e) Dark Green to Orange (11.2 ka? to $10.2 \mathrm{ka}$ )

Bay basin drained southeast along the edge of the ice sheet (Fig. 8a). There appears also to have been a great deal of flow from the northwest along the ice edge in the North Channel, which left major deposits in the False Detour Channel and the Mississagi Strait and which caused alternating deposition (dumping) and erosion in northwest Georgian Bay. There was little active flow in the modern Straits of Mackinac, which were then in the central region of Lake Kirkfield-Algonquin.

The large sediment accumulation west of the channel connecting Lake Huron and Georgian Bay indicates westward flow from Georgian Bay to Huron (Fig. 6f). This is one instance in which the sediment accumulation patterns apparently contradict flow directions indicated by other work (Lewis \& Anderson, 1989; Lewis et al., in review). This difference could be resolved by flow in both directions during the interval, with sediment accumulation peaking during westward flow. By around $11.4 \mathrm{ka}$, after the lowstand recorded by the Dark Blue sequence boundary, the sedimentation rates were fairly high (Table 1). However, there were areas (northwest Georgian Bay, the channel between Lake
Huron and Georgian Bay, and the Mississagi Strait and False Detour Channel) where erosion was active, probably towards the end of the interval as lake levels fell to the Dark Green lowstand. Georgian Bay appears to have drained westward into the Huron basin and then to the south during part of this interval. Oxygen isotopic ratios from shortly after the Dark Green lowstand indicate that Georgian Bay received more meltwater and/or was closer to the meltwater source than the other basins (Rea et al., 1994b). Either of these effects could have been enabled by downwarping of the crust due to a lobe of the ice sheet persisting to the west of the Huron-Michigan region over the Lake Superior basin (Lewis \& Anderson, 1989).

The 1000 years between the Dark Green and Orange sequence was the time of the Lake Algonquin highstand, the highest lake level recorded in this area in the last 12000 years (Fig. 7; Lewis \& Anderson, 1989). Deposition was almost entirely in the form of draping over bathymetry in Georgian Bay, but in Lake Huron some erosion and redeposition must have been taking place in shallow areas. (Fig. 8c). Little detail about 


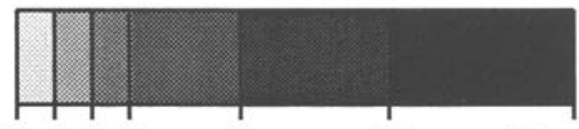
0123
$6 \quad 10$
15 meters

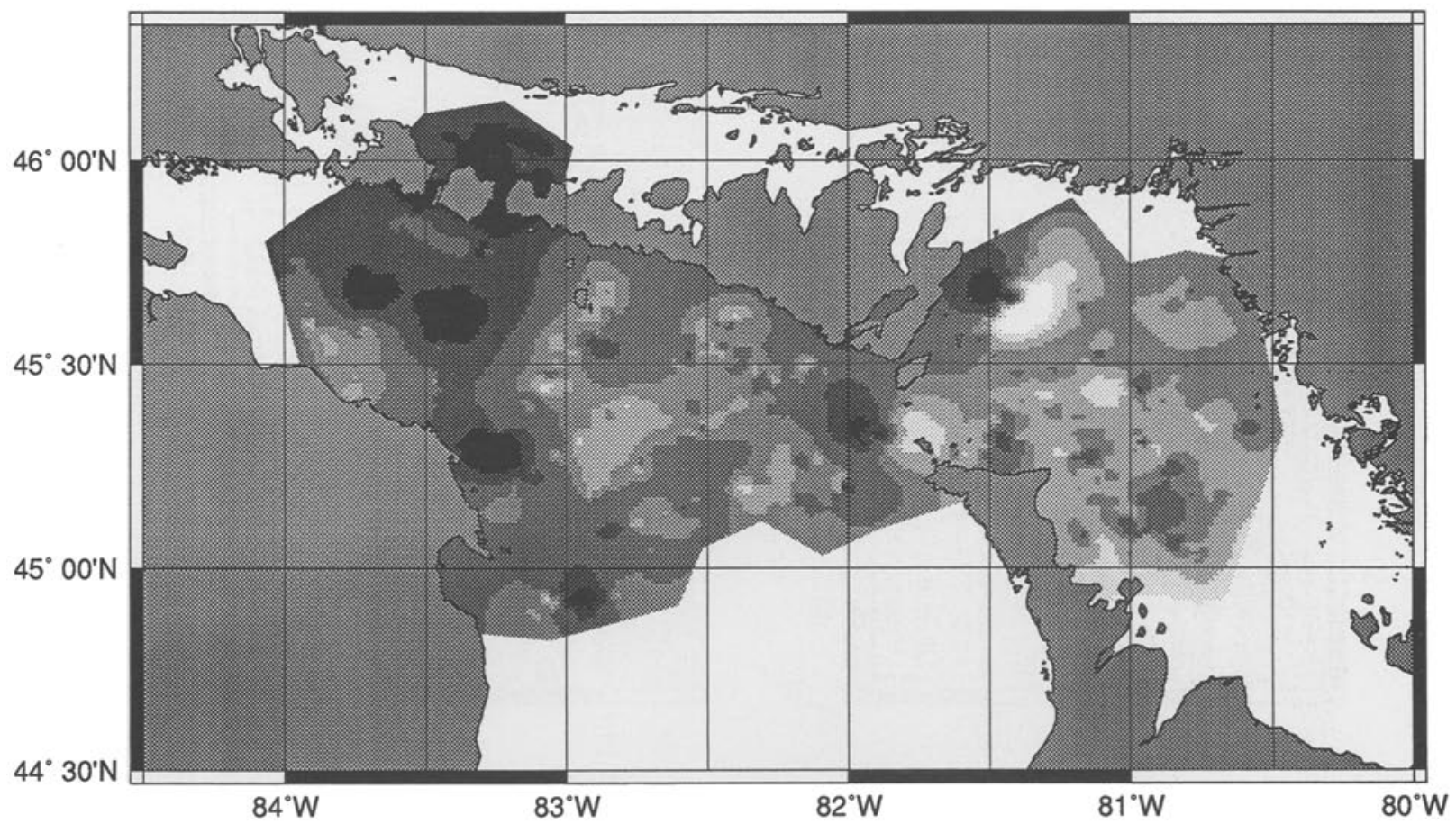

Fig. 6. (f) Purple (Acoustic Basement) to Dark Green (Ice retreat to $11.2 \mathrm{ka}$ ?)

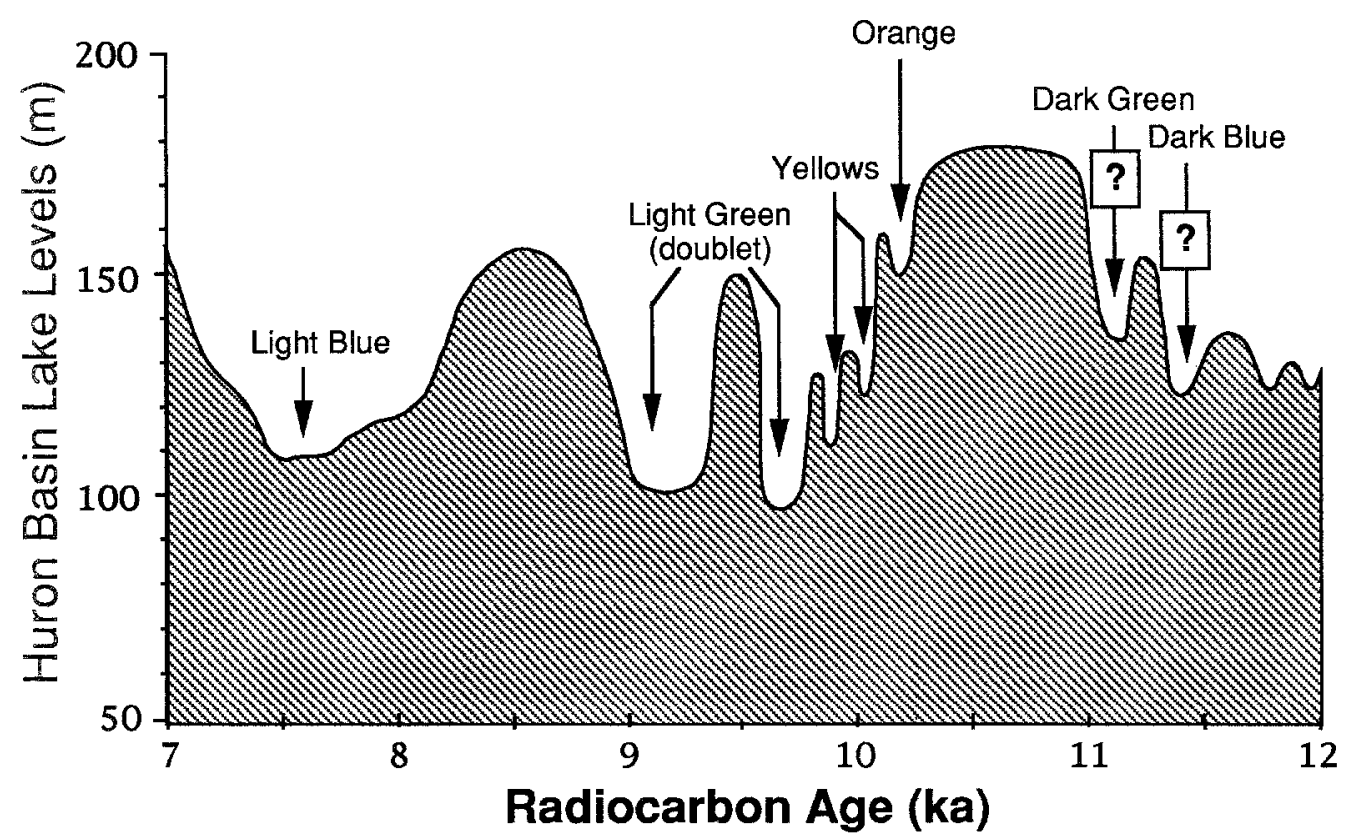

Fig. 7. Lake level history of the Lake Huron - Georgian Bay system (after Moore et al., 1994). Lake level indicated is the elevation of the lake surface above sea level in meters. 

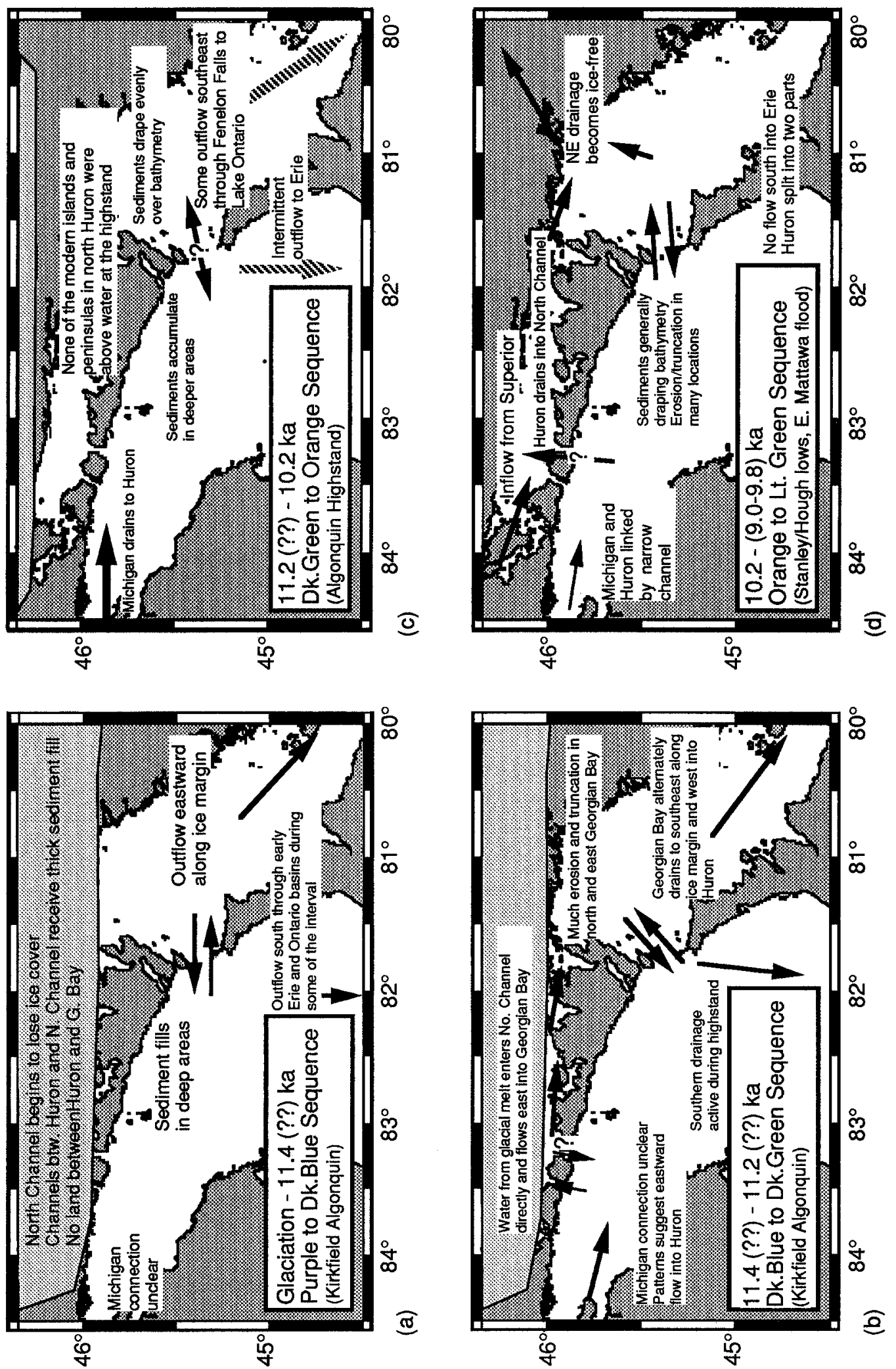

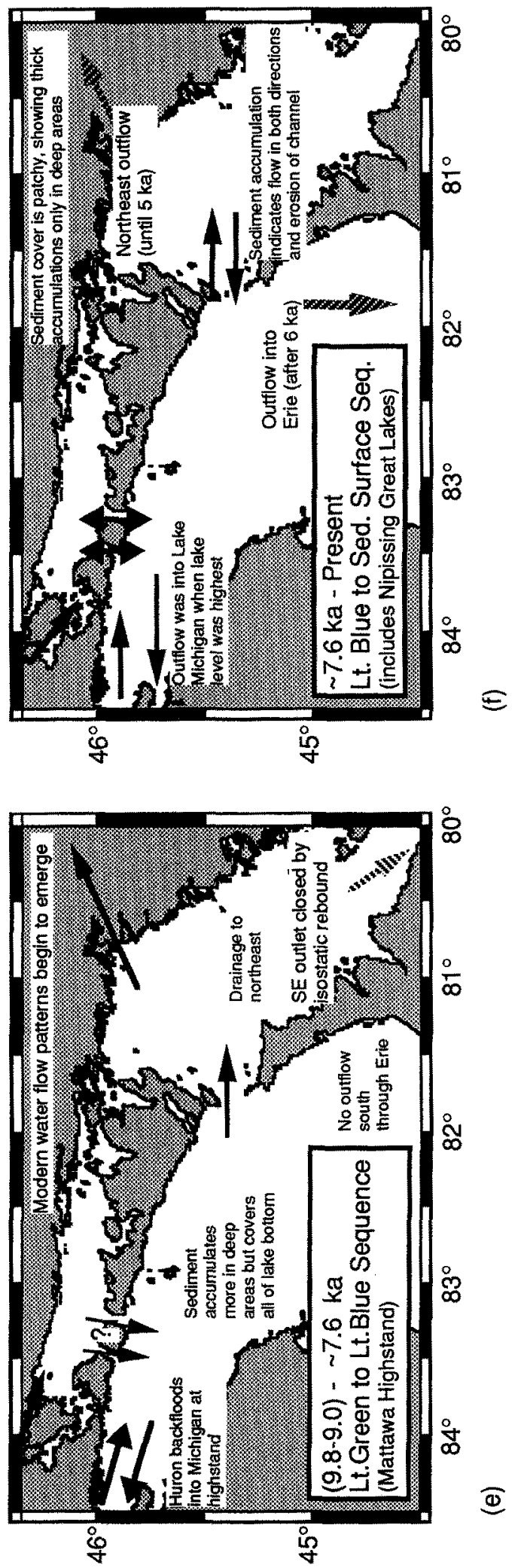

water flow can be determined from the sediment accumulation patterns because of their uniformity (Fig. 6e), but flow into the Huron basin from Michigan is likely responsible for the accumulations in northwest Lake Huron. Rea et al. (1994b) note that waters of southern Lake Michigan and northern Lake Huron are isotopically similar during the Lake Algonquin highstand, suggesting a free hydrological connection between the two areas.

After Lake Algonquin drained, a very rapid process which Lewis \& Anderson (1989) attribute to the retreat of ice from northeast of Georgian Bay, lake levels declined and fluctuated (Fig. 7). Sedimentation generally draped over bathymetry, but the patchy distribution of the Yellow sequence boundaries indicates that erosion must have been active during that interval. At the very low lake levels of the Light Green lowstands, Lake Huron was split by Six-Fathom Scarp into two basins connected by a narrow channel (Lewis \& Anderson, 1989), with Lake Stanley being the northern lake. Lake Stanley drained into the North Channel early in this interval, but this flow probably reversed direction after the Yellow lowstands (Fig. 6c). Lake Stanley also drained directly into Georgian Bay, and Lake Michigan drained eastward through the Mackinac River, which ran through the modern Straits of Mackinac. Rea et al. (1994b) show from isotopic records that southern Lake Michigan was characterized by local runoff at this time, while the Lake Huron basins were dominated by glacial meltwaters. The lake occupying the southern half of the Huron basin drained north into Stanley.

The Light Green sequence boundary marks two lowstands in quick succession in the period from 9800 to 9000 years ago. These were the lowest levels reached in these basins (Fig. 7; Moore et al., 1994) and form the main Stanley lowstand of previous works (collected and reviewed by Lewis \& Anderson, 1989). In between these lowstands, drainage must either have been from Georgian Bay westward into Lake Huron or the two basins were not connected at all, according to ostracode isotopic signatures (Rea et al., 1994b). This interpretation agrees well with Lewis et al.'s (1989) interpretation of isostatic rebound of lake outlets during this time. After these lowstands, the lake entered a new phase where sedimentation was characterized by pronounced infilling of deep areas and relatively thin cover over shallower areas - very different from the generally draping character of older sediments (Fig. 6b). This change was probably caused by erosion 
or non-deposition in shallower areas concomitant with reduced overall sediment supply.

With the rebound of the North Channel - Georgian Bay connection (Lewis \& Anderson, 1989), the North Channel drained primarily into northern Lake Huron (Fig. 8e). Lake Huron received inflow from North Channel, drained into Georgian Bay directly, and, during the rise in lake levels after the main Stanley lowstand, flowed back into the Lake Michigan basin, causing southern Lake Michigan to become isotopically more negative (Rea et al., 1994b). Between the time of the Light Green and the Light Blue horizons, waters in the Huron-Georgian Bay region rose to near their modern levels (the Mattawa highstand), and Rea et al. (1994b) indicate that the oxygen isotopic signature of northern Lake Huron rose from more negative meltwater values to meteoric values similar to those found in southern Lake Michigan.

The Light Blue lowstand at 7.45-7.75 ka represented the last major drainage event in these basins caused by the interplay of ice retreat and melting and isostatic rebound. Since this interval, sedimentation has been patchy and erosion common (Fig. 6a), and sedimentation has tended to fill deep areas. Sediment accumulations on either side of the channel connecting Lake Huron and Georgian Bay suggest that water has flowed through this channel in both directions over the last 7000 years (Fig. 8f). Erosion and very thin accumulation in the area near the Straits of Mackinac indicates that Lake Huron may have drained westward into Lake Michigan, probably during the higher lake levels of the Nipissing highstand around 4000 years ago, when the southern outlet through Chicago was active. There may also have been some northward drainage into the North Channel, but that would have occurred when the flow regime was generally westward. The sill between Thunder Bay and Duck Island is nearly bare of sediment, indicating erosion, and the Thunder Bay River may be responsible for the small accumulation in the Alpena Basin east of the bay.

Lewis \& Anderson (1989) have produced a detailed history of elevations of the inflow and outflow channels compared with lake levels in Lake Huron and Georgian Bay through time. Their models are based on rebound estimates, paleoshorelines, remains of terrestrial organisms in lake sediments, and a variety of other indicators. With some modifications, such as the changing direction of flow through the Mississagi Strait and False Detour Channel through time and the recent (post-Light Green) changes in water path through the Straits of Mackinac, the flow pat- terns derived from this work (Fig. 8a-f) agree quite well with the reconstructions in Lewis \& Anderson's (1989) paper.

\section{Conclusions}

The purpose of this research was two-fold. The primary aim was to determine the spatial and temporal distribution of acoustically-defined sediment packages in the Lake Huron and Georgian Bay basins. This was accomplished by using the comprehensive seismic survey coverage of these basins to produce isopachous maps of sediment thickness. These maps showed large changes in magnitude and distribution of sediment accumulations. They also showed apparent reversals in flow direction between Georgian Bay, the North Channel, and Lake Huron, in response to crustal rebound and opening and closing of drainage pathways and outlets. This comprehensive view of lake deposition reveals changes in linear sedimentation rate spanning nearly two orders of magnitude and reaching values of $5 \mathrm{~cm}$ $\mathrm{yr}^{-1}$ or more (Table 1).

Statistical analysis of digitized points and examination of the isopach maps shows a distinct change in character of sedimentation, from filling of bathymetric deeps (cf. very high maximum thickness for Dark Blue to Dark Green sequence, but relatively low mean thickness) to sedimentation which draped over bathymetry, with a more balanced range of means and maxima of thicknesses, and finally back again to filling of deep regions in more modern times.

The sediment accumulation maps also made possible a detailed reconstruction of flow pathways between Lake Huron, Georgian Bay, and the North Channel as they changed with the development of the lake. This information is very helpful in evaluating both the seismic stratigraphy and the sediment core data and in formulating hypotheses about Holocene lake levels, paleoclimate, and the geological effects of deglaciation in the Laurentian Great Lakes.

The secondary goal was to test the usefulness of three-dimensional surface-fitting in study of lacustrine seismic records. The isopach maps produced with this technique seem valid and are very useful in interpolating from the two-dimensional representation of the analog seismic records to a three-dimensional map of sediment accumulation. At a scale of observation of a few kilometers, they show depocenters and areas of erosion clearly and show whether sedimentation draped over or filled in large-scale bathymetric fea- 
tures. The technique could be refined, perhaps by testing the effects of the choice of tension factor or by enhancing gridding resolution, and undesired effects from the dependence of the method on presence of both horizons for thickness calculations could be examined and reduced. The surface-fitting has been demonstrated to be of use in study of records of this type.

\section{Acknowledgments}

We thank the Captain and the crew of the R/V Laurentian who were directly responsible for the success of our cruise. We also thank Larry Mayer and Mike Lewis for help in collecting and interpreting the data and Yuan Guan for assistance in digitizing the seismic data, and Mike Lewis and two anonymous reviewers for helpful discussion and review of this work. Funding for this work was provided by the National Science Foundation grant OCE 9101816.

\section{References}

Cameron, G., 1991. Seismostratigraphy of late Quaternary sediments and lake level history, eastern Lake Erie. MSc dissertation. Dalhousie University, Halifax, $157 \mathrm{pp}$.

Colman, S. M., G. A. Jones, R. M. Forester \& D. S. Foster, 1990. Holocene paleoclimatic evidence and sedimentation rates from a core in southwestern Lake Michigan. J. Paleolimnol. 4: 269-284.

Foster, D. S. \& S. M. Colman, 1991. Preliminary interpretation of the high-resolution seismic stratigraphy beneath Lake Michigan. Open-File Report 91-21, U.S. Geological Survey, 42 pp.

Graham, E. J. \& D. K. Rea, 1980. Grain size and mineralogy of sediment cores from western Lake Huron, J. Great Lakes Res. 6: 129-140.

Hutchison, D. R., C. F. M. Lewis \& G. E. Hunt, 1993 (in press). Regional stratigraphic framework surficial sediments and bedrock beneath Lake Ontario. Geographie physique et Quaternaire Special Volume Neotectonics of the Great Lakes Area.

Hough, J. L., 1958. Geology of the Great Lakes. University of Illinois Press, Urbana, $313 \mathrm{pp}$.

Johnson, T. C., 1980. Late glacial and post glacial sedimentation in Lake Superior based on seismic-reflection profiles. Quat. Res. 13: $380-391$.
Kemp, A. L. W., T. W. Anderson, R. L. Thomas \& A. Mudrovchva, 1974. Sedimentation rates and recent sedimentary history of Lakes Ontario, Erie and Huron. J. Sediment. Petrol, 44: 207-218.

Larsen, C. E., 1985. Lake level, uplift, and outlet incision, the Nipissing and Algoma Great Lakes. In P. F. Karrow and P. E. Calkin (eds.), Quaternary Evolution of the Great Lakes, Geological Association of Canada, Special Paper 30: 110-123.

Lewis, C. F. M. \& T. W. Anderson, 1989. Oscillations of levels and cool phases of the Laurentian Great Lakes caused by inflows from glacial Lakes Agassiz and Barlow-Ojibway. J. Paleolimnol. 2: 99-146.

Lewis, C. F. M., T. C. Moore, D. K. Rea, D. L. Detman, A. M. Smith \& L. A. Mayer, in review. Lakes of the Huron Basin: Their record of runoff from the southern Laurentide ice sheet. Submitted to Quatemary Science Reviews.

Moore, T. C., D. K. Rea, L. A. Mayer, C. F. M. Lewis \& D. M. Dobson, 1994. Seismic stratigraphy of Lake Huron - Georgian Bay and post-glacial lake level history. Can. J. Earth Sci. 31: 1606 1617.

Rea, D. K., R. A. Bourbonniere \& P. A. Meyers, 1980. Southern Lake Michigan sediments: Changes in accumulation rate, mineralogy and organic content. J. Great Lakes Res. 6: 321-330.

Rea, D. K., T. C. Moore, C. F. M. Lewis, L. A. Mayer, D. L. Dettman, A. M. Smith \& D. M. Dobson, 1994a. Stratigraphy and paleolimnologic record of early Holocene sediments in northern Lake Huron and Georgian Bay. Can. J. Earth Sci. 31: 1586-1605.

Rea, D. K., T. C. Moore, T. W. Anderson, C. F. M. Lewis, D. M. Dobson, D. L. Dettman, A. M. Smith \& L. A. Mayer, 1994b. Great Lakes paleohydrology: The complex interplay of glacial meltwater, lake levels, and sill depths. Geology 22: 1059-1062.

Rea, D. K., R. M. Owen \& P. A. Meyers, 1981. Sedimentary processes in the Great Lakes. Rev. Geophys Space Physics 19: 635-648.

Ristic, R. J., 1989. Lake Huron Bathymetric Chart and Morphometric Parameters, published privately.

Smith, W. H. F. \& P. Wessel, 1990. Gridding with continuous curvature splines in tension. Geophysics. 55: 293-305.

Teller, J. T., 1990. Volume and routing of late-glacial runoff from the southern Laurentide ice sheet. Quat. Res. 34: 12-23.

Thomas, R. L., A. L. Kemp \& C. F. M. Lewis, 1973. The surficial sediments of Lake Huron, Can. J. Earth Sci. 10: 226-271.

Vail, P. R., R. C. M. Mitchum, R. G. Todd, J. M. Widmier, S. Thompson, III, J. B. Sangree, J. N. Bubb \& W. G. Hatelid, 1977. Seismic Stratigraphy and global changes in sea level. In C. E. Payton (ed.), Seismic Stratigraphy - applications to hydrocarbon exploration, American Assoc. Petrol. Geol. Mem. 26: 49-212.

Wessel, P. \& W. H. F. Smith, 1991. THE GMT-SYSTEM v. 2.0 Technical Reference and Cookbook, SOEST/SIO. 